\title{
A CRITICAL ANALYSIS OF THE PRESENT STATE OF SYNAGOGUE RESEARCH AND ITS IMPLICATIONS FOR THE STUDY OF LUKE-ACTS. ${ }^{1}$
}

\author{
Stephen Catto
}

The form and function of the 'synagogue' 2 in the first century AD has been the focus of a great deal of recent scholarly discussion. A previous generation of scholars would have perceived a reference to a synagōge in a New Testament text as a monolithic institution with clearly defined functions, principally involving worship. Some recent scholarship has questioned many of these assumptions arguing that, in the first century AD, synagogee should be understood as a reference to a gathering and not a building. Similarly, it is noted that many of the reconstructions of what happened in a 'synagogue' are built on evidence that dates to a period much later than the first century.

This study argues that the debate has become too polarised between those who hold a minimal or maximal position on our sources, and that some of the issues concerned have not been thoroughly examined. In this thesis particular attention is paid to the geographical location and socio-economic background of our sources, which allows us to highlight possible differences in practice in various communities. It is argued that there was considerable diversity in what the 'synagogue' was like and how it functioned. In short, we should not assume that a 'synagogue' in Nazareth would look and function like one in Pisidian Antioch; to perceive the 'synagogue' as a monolithic entity and translate various terms with the English 'synagogue' is untenable.

After giving an introduction to the field and detailing the history of research in chapter 1 , chapter 2 assesses the relevant literary material

1 Abstract of a dissertation awarded a Ph.D. at the University of Aberdeen, 2005, supervised by Dr. Simon J. Gathercole.

2 Throughout the work inverted commas are used around the word synagogue where it is unclear whether a building or community is meant. 
available to evaluate the form of the 'synagogue' in the first-century period. It is argued that, in many towns and cities throughout Palestine, synagogue buildings would have existed. Similarly, in the Diaspora, where there was a Jewish population, they could also gather in buildings set aside specifically for the purpose; however, others would gather in domestic settings or in the open. The use of terms such as hieron by non-Jews to refer to the meeting places of Jews suggests that there were similarities in appearance or function between the synagogue buildings and pagan temples.

A particular focus of this work is the available archaeological evidence. In chapter 3, potential first-century synagogue sites are discussed in detail, including archaeological remains which have been long identified as synagogue buildings. New discoveries are aiding the discussion of first-century Judaism generally, and 'synagogue' studies have benefited from a number of recent finds which, it has been proposed, are synagogue buildings (e.g. Jericho, Khirbet Qana, Qiryat Sefer). The relative merits and shortfalls of the identification of these sites are included, as is a discussion of what they might bring more broadly to our understanding of first-century Jewish practice. The building in Ostia has been the subject of considerable debate, and this study includes a CD with a computer generated 'walk through' model of what the building may have looked like in the first century period. A comparison with the buildings of voluntary associations in Ostia highlights areas of similarity. Again, the archaeological evidence points to variety within the buildings used by the Jews, and facilities such as triclinia indicate that they fulfilled various functions.

Having discussed their form in the first century, chapter 4 highlights the range of sacred activities that could have taken place within a 'synagogue', including a critique of false understandings of what might constitute worship in this period. The sanctity of both the place and the person was important, and practices to bring about ritual cleansing in the Diaspora appear to have been different to those in Palestine: it is argued that Diaspora Jews were influenced by practices in the wider Greco-Roman world. While Scripture reading and teaching are clearly identified with the 'synagogue', it has been argued that communal prayer was not a part of its function. However, evidence is gathered which counters such a position, and the identification of some of the Jewish meeting places as proseuchai would appear to strengthen this notion. Whilst it is agreed that the fixed prayer of the Amidah was not 
fully formed in the early first century, the documents from Qumran identify patterns of prayer that can also be seen in other material from the Second Temple period. It is suggested that similarities in themes found in the liturgies from Qumran and later rabbinic sources suggest a broad stream, drawing on biblical motifs, which found expression in slightly different ways in diverse communities and at different times. In addition to these more commonly identified liturgical functions, it is argued that communal meals were part of Jewish community life, that it is likely that these took place within 'synagogues', and that they would have included a ritual element.

Having gathered the available data on the form and function of the 'synagogue' in the first century $\mathrm{AD}$, chapter 5 then compares this material to the presentation of the 'synagogue' in Luke-Acts, using it better to inform our exegesis of texts. Potential differences between 'synagogues' in diverse geographical locations, as well as the impact of the social standing of the Jews within particular communities, are discussed using the references to synagogai in Judea, Galilee and Phrygia, as well as the proseuche in Philippi (which should not be understood as a synagogue building). The remains of a first-century synagogue building in Capernaum, combined with the other material gathered, allow a careful reconstruction of what that building may have looked like, including its seating capacity, as well as a discussion of its role in the public life of the community. In the same way, an analysis of Luke's presentation of worship practices is assessed against previous evidence, with possible differences in procedure highlighted between a small rural village in Galilee (e.g. Luke 4:16-30) and a large Roman colony in the Diaspora (e.g. Acts 13:13-43). It is also suggested that certain 'synagogues' such as those mentioned in Acts 6, although in Jerusalem, would have reflected Diaspora practices.

As well as informing our exegesis of particular New Testament texts, this study also illuminates one of the important first-century Jewish institutions and as such provides good background material in understanding the social setting for historical Jesus research. Further, the variegated nature of the first-century 'synagogue' will need to be incorporated into any discussion of its influence on the worship of the early church. 